\title{
The sociomaterial in archivist practices from post-qualitative research perspective ${ }^{1}$
}

\author{
Patrícia Maria da Silva² \\ Universidade Federal da Paraíba / Federal University of Paraíba (Brazil) \\ silva.131313@gmail.com, ORCID 0000-0002-9415-0629
}

\begin{abstract}
Life in society shows that we are made up of several elements that shape us and associate us with the world. Thus, it is necessary to study theoretical perspectives that are able to highlight the role played by a diverse range of actors, configuring themselves as an assembly of things. However, it is quite common to consider that in archival practices, humans are generally perceived in a hegemonic way, whose objects/things, documents, are always passive to the action of these humans. I bring performativity and post-qualitative research to the theoretical debate, because I understand that objects/things must also be included in the analysis of a phenomenon, as they make up the process by which a given phenomenon unfolds. Methodologically I presented post-qualitative research, based on a nonanthropocentric view, unmasking the ways in which we are rooted in humanist ideologies, post-qualitative research offers a way of being in the world that fits and can engage the tangle that the world is. I believe that non-humans can be carriers of practices and have performances, just like humans. We need to show how the things that people do, make people do things. I do not intend to place objects/things above humans, or vice versa, but between them and vice versa. These objects/things can be used by us humans, but they can also use humans and influence, change an archival social practice, which then is no longer particularly human.
\end{abstract}

\author{
KEYWORDS \\ sociomateriality, \\ archival practices, \\ post-qualitative \\ research
}

\section{Społeczno-materialny aspekt praktyki archiwalnej z perspektywy badań postjakościowych}

\section{STRESZCZENIE}

Życie w społeczeństwie pokazuje, że składamy się z wielu elementów, które nas kształtują i wiążą ze światem. Konieczne jest zatem badanie perspektyw teoretycznych, które są w stanie uwypuklić rolę, jaką odgrywają różnorodne podmioty, konfigurujące się jako zbiór rzeczy. Dość powszechnie uważa się, że w praktyce archiwalnej ludzie są zazwyczaj postrzegani
SŁOWA KLUCZOWE perspektywa społecznomaterialna, praktyka archiwalna, badania postjakościowe

1 This article was published in Portuguese in the Brazilian journal "Archeion Online" in 2020 (https://periodicos.ufpb.br/ojs/index.php/archeion/article/view/52976. Accessed: 30.12.2020).

2 Profa. Dra. Department of Information Science (DCI / UFPB). Graduate Program in Management in Learning Organizations (MPGOA / UFPB). Post-doctoral student in Education (FACED / UFBA). PhD in Education (FACED / UFBA). Master in Information Science (UFPB). 
w sposób hegemoniczny, a przedmioty/rzeczy, dokumenty są zawsze bierne wobec działań ludzi. Autorka wnosi do debaty teoretycznej performatywność i badania postjakościowe, stawiając tezę, że przedmioty/rzeczy muszą również zostać włączone do analizy zjawisk, gdyż są elementami składowymi procesu, w ramach którego dane zjawisko się rozwija. Od strony metodologicznej przedstawiono badania postjakościowe, oparte na nieantropocentrycznym punkcie widzenia, obrazujące sposoby, w jakich jesteśmy zakorzenieni w ideologii humanistycznej; badania postjakościowe oferują sposób bycia w świecie, który wpisuje się w skomplikowany system, jakim jest świat, i umożliwia angażowanie się w jego działanie. Autorka stwierdza, że nie-ludzie mogą być nosicielami praktyk i odgrywać role, tak samo jak ludzie. Pokazuje, w jaki sposób powstaje interakcja między ludźmi a przemiotami, które wykonują. Nie stawia przedmiotów/rzeczy ponad ludźmi, ani odwrotnie, ale w relacji pomiędzy nimi. Przedmioty/rzeczy mogą być używane przez ludzi, ale mogą też „używać” ludzi i wpływać na archiwalną praktykę społeczną, która wówwczas nie jest wyłącznie wytworem ludzi.

\section{Introduction}

Life in society demonstrates that we are made up of several elements that shape us and associate us with the world (Le Breton, 2003; Haraway, 2009; Couto, 2012). In other words, the human is both a singularity and a sum of bonds.

The concept of the social has many different meanings, however the Latin word socius, which means to associate, has a sense of including anything and everything that can be associated. Thus, the social (connections, interactions) can include plants, animals, artifacts, humans, objects/things, etc.

The social is what manifests itself from the associations, and how these associations stabilize, producing the social (Latour, 2012). The social and the material are deeply connected and there is no social that is not material, and no material that is not also social (Buhl; Andersen; Kerosuo, 2019).

In this context, the argument developed in this theoretical article is that life, both in the archival area and in other spheres, is never just material and social. Far from being passive or inert, materiality is a living force that actively participates in events (Bennett, 2010a) and has a performativity. Thus, archivist professionals are surrounded by objects/things: shelves, mobile files, equipment, administrative hours, political documents, etc., it is impossible to imagine Archivology happening without them (Waltz, 2006).

Political documents can be defined as material/immaterial objects, which has an effect on the social environment. It means arrangements of power and authority, for example, the table of temporality and destination of documents. 
That said, it is important to focus the article's attention on the social and materiality, and especially on performativity, if we want to understand these interactions. The agendas used in Archivology lack a methodology that would start not only with human beings, their goals and interests, but also with interdisciplinary fields.

In this way, performativity and post-qualitative research are brought into the theoretical debate, because it is understood that objects/things also need to be included in the analysis of a phenomenon, as they make up the process by which a given phenomenon unfolds.

Therefore, it is important to present new concepts and questions, to discuss archival issues, challenging hierarchies of Cartesian thought and its central binarisms (particularly society / nature, human /non-human ${ }^{3}$ ), based on several factors, such as more access to information and consumer goods - effects of globalization and its economies. In addition, environmental catastrophes, wars, gender violence, racism, lack of privacy, the era of the algorithm ${ }^{4}$ and, more recently, the Covid-19 pandemic.

\section{Sociomaterial perspective}

How is contemporary archivology leading to materiality? This is an essential question to be discussed by researchers, and the answer is in working on a flat ontology, treating materiality as part of society and thus demonstrating the importance of non-humans in human dynamics and interactions.

Such a divergent approach, of looking at what we call flat ontology, is known as a 'sociological turn', which tends to decree a symmetry between social actors (human and non-human), distancing itself from the classic dualist and polarized understandings of the world, of good and evil, of true and false, of good and bad, of human and non-human, and thus, establishing non-dichotomized dialogues.

3 Although it seems explicit, the term non-human constitutes everything that is not human: material and immaterial objects, plants, animals, texts, architecture, laboratories, machines, artifacts, organisms, things of nature, etc.

4 In connected societies, decisions about life are influenced by machines and codes; these artificial brains are able to to draw an automated picture of their subscribers' tastes and build a suggestion machine. For example, users of streaming music, receive a personalized list that allows them to discover new songs and artists. Same goes for the recommendation systems of Amazon, Google, eBay and Facebook, among others. 
Ontology is a part of philosophy that studies being at its beginnings. The concept of ontology used here sees reality as dynamic and performative, emerging through sociomaterial practices (Postma, 2012). In this sense, there is a wealth of possibilities to explore how Archivology is articulated in a network of practices, appreciating the multiple ontologies, where no human and/or non-human actor exists without being articulated to the practices that produce and make it exist.

The flat ontology works from the perspective that people and objects occupy the same level of hierarchy (figure 1).

Figure 1 - Layout of the Flat Ontology

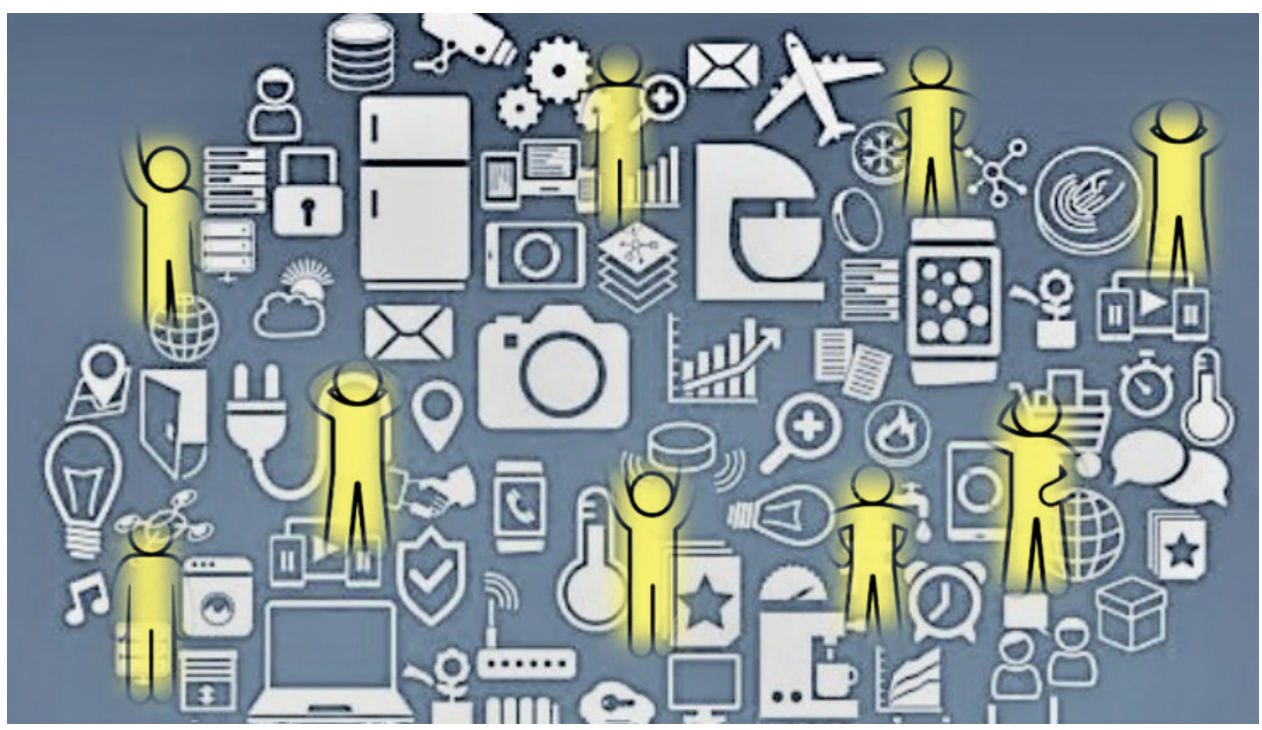

Source: Prepared by the Author, 2020.

According to Hatton (2019), in the flat ontology the real world is understood as constituted by the interactions between various assemblies of heterogeneous elements (things, people, technologies, texts, etc.), and such interactions generate significant transformations, because each time an entity comes into existence, all its effects become significant.

"Thinking about subjects without objects, or objects without subjects, can only be a' magic 'or artifice in purifying hybrids ${ }^{5}$ and thinking about the social in a simplistic way" (Lemos, 2012, p. 37). Strengthening this perception, Latour

5 Hybrid refers to something that results from the mixture of two or more different elements. 
(1994a) says that we are all quasi-subjects and quasi-objects, and the more we are one, the more we are the other.

Let's look at an example of a football match. The ball in play does not mean the same thing as the set ball. Note that the ball in play makes it possible to gather and aggregate a community, the ball in this sense is a quasi-object that produces reality. It is the power of things (ball) to invoke the activity of quasi-subjects (Bennett, 2010b).

The ball stopped before or after the match does not exist, as it has no function or meaning, it has no action. Objects, materials, bodies, nature, technologies, configurations, etc., allow some actions and prevent others.

\section{Archivistic social practices}

Work on social practices can be conducted from multiple ontological and epistemological perspectives, generating a variety of paths for research. One of these different approaches was chosen, treading towards the 'practice turn', specifically by the Theory of Social Practice (TPS), originating from Philosophy, and influenced by Theodore Schanktzi ${ }^{7}$, post-structuralist (Moura; Diniz, 2016).

Studies based on theories of practice form a large umbrella that encompasses a conglomerate of theories. However, the choice of working with TPS, not in its entirety, but as an inspiration to discuss archival practices, is at the heart of the understanding that the backbone of practices starts from the assumption of a relational dynamics that links subjects and objects/things (Knnor-Cetina, 2001), that is, the field of practices is composed of material interlacing.

The relational dynamics emphasizes the impact of all relationships and how humans and objects/things are transformed, when they are entangled from the arrangements and their effects (Sørensen, 2009). With regard to the arrangements, they are arrangements and organizations of 'things' in the world, or rather, of the parts that make up the whole. They are layout of humans and non-humans that relate and occupy places in relation to each other.

6 Movement generated by studies of practices, and seeks, in essence, to overcome traditional dichotomies or polarizations "(Alvarenga, 2017, p. 96).

7 Professor of Philosophy at the University of Kentucky (Texas, USA), and co-director of the Social Theory Committee of the same institution. 
TPS seeks to articulate that the field of practices is the place to investigate phenomena, and when we speak of practices, in general, we think of matrices of activities to be developed in a given context (Schanktzi, 2001a; 2001b). However, it does not come to mind that such activities are mediated and propagated by artifacts, objects/things, hybrids, relevant to practices more than mere intermediaries, that is, objects/things not only mediate, but propagate practices.

Practices are arrangements of people and artifacts, things/objects, organisms, etc., by which they coexist; these entities ${ }^{8}$ are related and have identities (who they are) and meanings (what they do) (Schanktzi, 2001a; 2001b). They are conceived, however, as actions internal to individuals (Barnes, 2001), and thus make other entities invisible in the field of practices. However, understanding that they are shared by objects/things are central issues for the understanding of social phenomena.

Barnes (2001) uses the example of acupuncture: alternative medicine, in which fine needles are inserted into the patient's body. It is not the penetration of needles without thinking, it involves a joint action between human subjects and objects/things; the acupuncturist interacts with the patient, but also with the needles and vice versa, so that it involves a combination of agents (human and non-human) to reach a specific end.

Bringing another example, one from the archival field this time, we can think of the techniques of identification, description, preservation, etc., as methods and processes in the archival, a connection between the professional of the archive (human) and the archival document (objects/things).

According to Rossato and Flores (2015), an archival document is one produced, in any medium, by an individual or legal entity in the performance of its activities. It has four characteristics considered basic, namely:

1. Naturalness - refers to the production of the archival document within a natural process of activity in which it was created;

2. Authenticity - it is authentic when created and maintained according to procedures that can be proven from pre-established routines;

8 According to Fenwick and Edwards (2010), the term 'entity' was adopted by Latour to represent human and non-human elements. The use of this expression eliminates the idea of ascribing higher value to one of the elements (human or non-human). It is a way of referring to various things, that can be human and non-human, including different types of material objects and immaterial objects (conceptual, moral, virtual) and actions, which are not pre-determined, essentialized and defined. 
3. Organicity - refers to the relationship that the archival documents have among themselves in the course of the actions for which they were created;

4. Uniqueness - It refers to assuming a unique place in the documentary ordering of the collection to which it belongs.

It is also important to point out the social function of archival documents. According to Moura and Vaisman (2017), for society to recognize the social function of archival documents, it is important that we go beyond the idea of exclusively legal function of such documents, but also to recognize their social responsibility, in what corresponds to the transmission of individual and collective memories and production of knowledge (Campo, 2017; Rodrigues, 2008).

Note that these associations are hybrid, and are interpreted as arrangements of humans and non-humans, through which they coexist in a network. However, it is quite common to consider that in archival practices, humans are generally perceived in a hegemonic way, whose objects/things, archival documents, are always passive to the action of these humans. Thus, it is necessary to study theoretical perspectives that are able to highlight the role played by a diverse range of actors, configuring themselves as an assembly of things (Lupton, 2015).

This is not to say that there are no differences between humans and nonhumans; the approach taken here is analytical. It is alleged that these differences, this separation, is not essential for understanding social phenomena, including in Archivology. "As long as humanism is done in contrast to [non-humans], we will understand neither one nor the other" (Latour, 1994, p. 134). It does not seem to be an option, as the social and physical / material worlds are totally interconnected. Everything is hybrid.

Thus, it is understood that it is impossible to consider archival practices simply and only as the execution of a task for humans. And that these humans are the only ones that have performativity.

\section{Archivistic performance}

When it comes to performance, the first thing that comes to mind is human performance/ interpretation, as we are used to thinking from a humanistic point of view, regardless of all non-human behaviors measured or captured in terms of performance or performative acts. 
Although the word performance has several meanings, in this article, we use the meaning attributed to it by Annemarie Mol (2002; 2008). Performativity has to do with the concept of action; objects / things have action, because associated with humans, they dynamize flows and intensities, which lead to the social fabric, producing differences, deviations and transformations. In other words, the performative expression understands that the world is full of actions and that these actions no longer comprise human actors alone.

The action can also be exhibited by beings who are not capable of intentional action, that is, by objects/things, and therefore, the action can be explained without reference to mental states (Schlosser, 2015), and these objects/things also perform.

Let us look at another example of the action of archival documents (objects/ things) in archival practices. The table of temporality and destination of documents, an instrument that is used to define the life cycle of archival documents. Note that it is the documents themselves that perform their stages, whether they are permanent, temporary custody or their elimination. The archivist and the archival documents, act together collectively through their attributes.

Who performs, the archivist or the archival documents? I would say both at the same time. The professional cannot act alone without the table of temporality and destination of documents, and consequently, without the archival document; the archival document cannot move on its own either. In the process, the temporality table/document destination and the archivist are merged, the two become one, linked by a power that operates over all entities. Together, they become "[...] toolbody, machine-body" (Foucault, 1987, without pagination).

The distinction between things and people is much less important than the performance they provide and the fusion of their social effects (Waltz, 2006). As actors, people are not categorically different from things. Both are social actors who perform the world together with a variety of other actors: human and non-human.

Performance is the mechanism through which everyone relates to each other, regardless of any differences or the real complexity of their structures; the examples cited earlier are a good point of observation. Performativity is understood not as an 'act', but as a practice named and produced by discourse (Butler, 2001), it is a sine qua non of all forms of relationality (Florêncio, 2014).

Therefore, we understand that relationality, according to Law (1992, p. 389, our translation), treats “agents, organizations, and devices as interactive effects", 
emphasizing the impact all relationships (human and non-human) have on each other.

To make the statements more concrete and at the same time present a methodological alternative to the field of Archivology, a way of being in the world is presented, which fits in and can involve the entanglement of objects / things and humans that the world is. Thus, methodologically deconstructing the human being as a locus of archival social practices, I present post-qualitative research (St. Pierre, 2018a; 2018b; Le Grange, 2018; Ulmer, 2017; Gerrard; Rudolph \& Sriprakash, 2017).

\section{Post-qualitative research}

Post-qualitative research has emerged in recent years as a methodological movement situated within the broad 'sociomaterialist turn' (Gerrard; Rudolph; Sriprakash, 2017). For this movement (materialist turn), there is no world out there separate from humans, but a dynamic interrelationship between different materialities (Pennycook, 2018; Barad, 2003).

Thus, post-qualitative research is dynamic, fluid, indefinite, unfolding. It marks a break with the qualitative humanistic methodology, attracting, for this form of research, the agency realism (Barad, 2007), the power of things (Bennett, 2010a) and the networks of multiplicities (Deleuze; Guattari, 1996), incorporating the post-structuralism and in this way, deconstructing one of the most powerful forms of humanism - the human being.

Involvement with post-qualitative research implies profoundly different ways of thinking about research design. Post-qualitative research adopts more open, flexible and descriptive measures. The important thing is to arrive at an integrated understanding of the relational composition of a specific practice under investigation, and the effects that these compositions generate. Thus, all the forces that acted on and through research, for example human and nonhuman, came together to produce a set of post-qualitative research, becoming an entanglement, an assembly of things (Mazzei, 2013).

Therefore, the entry point in the post-qualitative analysis is to consider it as an assembly of things, since the multiplicity in the process to be researched (humans, objects/things, scenarios and physical spaces, scientific literature 
and previous studies, theoretical assumptions, data produced by methods and techniques, etc.) seeks the effect that unites this assembly (Fox; Alldred, 2017).

Taylor (2017) identifies some key characteristics of post-qualitative research, they are:

1. Decentralization of humans in order to recognize the action of non-humans as well.

This characteristic defends that we need to go beyond the idea of uniqueness of the subjects (humans) and embrace a material world also due to the interference of other agents (non-humans) (Pickering, 2001).

2. The shift from cognitive awareness to relational materialism.

In general, we understand that it is the distinction between the behavior produced by mental states, that is, by an intentional (human) action, and the behavior that can be explained in material (non-human) causal terms. It is the distinction, for example, between a person telling another person that it is time to go, and an alarm clock set to alert the person that it is time to go.

3. Epistemological reformulation that rejects the binarism of the Cartesian subject and, consequently, the overcoming of the subject / object dichotomy. The binary that Humanism has instituted, and that has been used to mark the human as a category of being separate, exceptional, distinct, privileged and superior to the rest of life in the universe, is illegitimate and fallacious. The belief that binary limits between subjects and objects / things are limited and harmful to the understanding of the social, and that these limits can no longer be used comfortably.

Post-qualitative research does not have a conceptual consensus, as it is structured around several theoretical assumptions (rhizomatic networks, agency realism and the power of things). It is interesting to start post-qualitative research from a post-structuralist analysis (St. Pierre, 2018a; 2018b) described by key characteristics.

For Lather and St. Pierre (2013) the categories we invented to organize and structure the qualitative humanistic methodology, for example: research problems and issues, methods of production and data analysis (interviews, questionnaires, focus groups, etc.), presuppose the depth in which the human being is superior and separated from the material.

For post-qualitative research, phenomena are described and explored as arrangements, as sociomaterial configurations of the world, and any point has 
the power to be connected to any other, acting as living matter in the assembly of humans and/or non-humans.

Thus, by decentralizing humans as the only possible connoisseurs and knowledge producers, a wealth of research possibilities arise (Ulmer, 2017) offering another reformulation in alignment with a new set of philosophies about the social (Greene, 2013).

\section{Final considerations}

We, humans, use tools and technologies, that is objects/things, to increase our capabilities and our senses, and these non-humans produce profound changes in knowledge, behavior, and culture.

Therefore, it is important to awaken non-humans, who are intertwined; intertwined, because objects/things are not a backdrop in social contexts (home, work, leisure, etc.), but rather respectable actors, even in archival environments.

Understanding that the production of scientific facts does not come only from humans, but from associations and, consequently, from the mixes of the entities, means that methodologically, we present the post-qualitative research.

Based on a non-anthropocentric view, unmasking the ways in which we are rooted in humanist ideologies, post-qualitative research offers a way of being in the world that fits in and can engage the tangle that the world is.

Post-qualitative research analyzes how material forces affect the conduct of daily life, discusses how and when non-humans act and explore the methodological value of materiality studies in order to highlight the poorly studied forms of social life.

Thus, objects/things are not merely instruments to 'record or reproduce human voice' they also 'speak and act', however, moderns (LATOUR, 1994), unlearned the language, the language of objects/things, because they isolated such entities within the logic of practical reason, such as utilitarian or ornamental resources. The language of objects/things comes from their own particularities, which suit the cultural purposes for which they are inscribed (Gonçalves; Bitar; Guimarães, 2013; Braun; Whatmore, 2010).

According to Pickering (2013), we humans are performative agents, we do things in the world, however, things/objects (stones, archival documents, stars, tools, etc.) also do it, that is, they also perform. 
I believe that non-humans can be carriers of practices and have performances, just like humans. We need to show that we do things, but these things also make us do. These objects/things can be used by us humans, but they can also use humans and influence, change the archival social practice, which then is no longer particularly human.

\section{References}

ALVARENGA, G.L. A Practice Turn nos Estudos Organizacionais Brasileiros: Uma Análise de Publicações entre os Anos 2006-2015. Pensamento \& Realidade, v. 32, n. 1, p. 93-106, 2017.

BARAD, K. Meeting the universe halfway. Quantum physics and the entanglement of matter and meaning. 2007. Available in: https://smartnightreadingroom.files.wordpress.com/2013/05/ meeting-the-universe-halfway.pdf. Accessed 24.07.2019.

BARAD, K. Posthumanist Performativity: Toward an Understanding of How Matter Comes to Matter. Journal of Women in Culture and Society, v. 28, n. 3, p. 801-831, 2003.

BARNES, B. Practice as collective action. In: SCHATZKI, T.R.; KNOR-CETINA, K.; VON SAVIGNY, E. The Practice Turn in Contemporary Theory. London, New York: Routledge, 2001.

BENNETT, J. Thing-Power. In: BRAUN, B.; WHATMORE, S.J. Political Matter: Technoscience, Democracy, and Public Life. Minnesota: Univerversity of Minnesota Press, 2010a. p. 35-62.

BENNETT, J. Vibrant Matter: A Political Ecology of Things. Carolina do Norte, USA: Duke University Press, 2010b.

BRAUN, B.; WHATMORE, S.J. The Stuff of Politics: An Introduction. In: BRAUN, B.; WHATMORE, S.J. Political Matter: Technoscience, Democracy, and Public Life. Minnesota: Univerversity of Minnesota Press, 2010. p. ix-xl.

BUHL, H.; ANDERSEN, M.; KEROSUO, H. I Work All Day with Automation in Construction: I am a Sociomaterial-Designer. In: NORDIC CONFERENCE ON CONSTRUCTION ECONOMICS AND ORGANIZATION, 10., 2019. Available in: https://doi.org/10.1108/S2516285320190000002018. Accessed 2.06.2019.

BUTLER, J. Corpos que pesam: sobre os limites discursivos do "sexo". In: LOURO, G.L. (org.). O Corpo Educado: pedagogias da sexualidade. 2. ed. Belo Horizonte: Autêntica, 2001. p.152-172.

CAMPOS, J.F, G. Arquivos pessoais: facetas de um dilema. In: ANDRADE, A.C.N. (Org.). Arquivos, entre tradição e modernidade, volume 2: trabalhos apresentados nas sessões de comunicações livres e os eventos paralelos do XI Congresso de Arquivologia do Mercosul. São Paulo: ARQ-SP, 2017. p. 39-49. 
COUTO, E.S. Corpos voláteis, corpos perfeitos: estudos sobre estéticas, pedagogias e políticas do pós-humano. Salvador: Edufba, 2012.

DELEUZE, G.; GUATTARI, F. Mil platôs - capitalismo e esquizofrenia. Rio de Janeiro: 34, 1996. V. 3.

FENWICK, T.; EDWARDS, R. Actor-Network Theory in Education. London, New York: Routledge, 2010.

FLORÊNCIO, J. Ecology Without Nature, Theatre Without Culture Towards an Object-Oriented Ontology of Performance. O-Zone: A Journal of Object-Oriented Studies, v. 1, p. 118-127, 2014.

FOUCAULT, M. Vigiar e punir: nascimento da prisão. Petrópolis: Vozes, 1987.

FOX, N. J.; ALLDRED, P. Social structures, power and resistance in monist sociology: (new) materialist insights. Journal of Sociology, v. 54, n. 3, p. 315-330, 2018.

GERRARD, J.; RUDOLPH, S.; SRIPRAKASH, A. The Politics of Post-Qualitative Inquiry: History and Power. Qualitative Inquiry, v. 23, n. 5, p. 384-394, 2017.

GONÇALVES, J.R.S.; BITAR, N.P.; GUIMARÃES, R.S. A alma das coisas: patrimônio, materialidade e ressoanância. Rio de Janeiro: Mauad X, 2013.

GREENE, J.C. On rhizomes, lines of flight, mangles, and other Assemblages. International Journal of Qualitative Studies in Education, v. 26, n. 6, p. 749-758, 2013.

HARAWAY, D. Manifesto ciborgue Ciência, tecnologia e feminismo-socialista no final do século XX. In: HARAWAY, D.; KUNZRU, H.; TADEU, T. (Org.) Antropologia do ciborgue: as vertigens do pós-humano. 2 ed. Belo Horizonte: Autêntica, 2009, p. 33-118.

HATTON, N. A Tale of Two Pianos: Actants, Sociability, and Form in Jane Austen's Emma. Open Cultural Studies, v. 3, p. 135-147, 2019.

KNORR-CETINA, K. Objectual practice. In: SCHATZKI, T.R.; KNORR-CETINA, K.; VON SAVIGNY, E. (Ed.). The practice turn in contemporary. London: Routledge, 2001. p. 184-197.

LATHER, P.; ST. PIERRE, E.A. Post-qualitative research. International Journal of Qualitative Studies in Education, v. 26, n. 6, p. 629-633, 2013.

LATOUR, B. Jamais fomos modernos: ensaio de antropologia simétrica. Rio de Janeiro: 34, 1994.

LATOUR, B. Reagregando o Social: uma introdução à teoria do Ator-rede. Salvador: Edufba, 2012.

LAW, J. Notes on the Theory of the Actor-Network: Ordering, Strategy and Hetereneity, Systems Practice, v. 5, p. 379-93, 1992.

LEMOS, A. A comunicação das Coisas. Internet das Coisas e Teoria Ator-Rede. Etiquetas de Radiofrequência em Uniformes Escolares na Bahia. 2012. Available in: http://docplayer.com. br/659634-A-comunicacao-das-coisas-internet-das-coisas-e-teoria-ator-rede.html. Accessed 15.02.2017.

LE BRETON, D. Adeus ao corpo: antropologia e sociedade. Campinas: Papirus, 2003. 
LE GRANGE, L. What is (post)qualitative research? South African Journal of Higher Education, v. 32, n. 5, p. 1-14, 2018.

LUPTON, D. Personal Data Practices in the Age of Lively Data. 2015. Available in: https://papers. ssrn.com/sol3/papers.cfm?abstract_id=2636709. Accessed 10.01.2019.

MAZZEI, L.A. A voice without organs: interviewing in posthumanist research. International Journal of Qualitative Studies in Education, v. 26, n. 6, p. 732-740, 2013.

MOL, A. Política ontológica: algumas ideias e várias perguntas. 2008. Available in: https://pure. uva.nl/ws/files/899834/77537_310751.pdf. Accessed 8.01.2018.

MOL, A. The Body Multiple: Ontology in MedicalPractice. London, Duke University Press, 2002. Available in: https://edisciplinas.usp.br/pluginfile.php/4621896/mod_resource/content/2/ MOL\%2C\%20Annemarie.\%20The\%20body\%20multiple.pdf. Accessed 15.12.2019.

MOURA, L.E.; VAISMAN, P.S. Exposição: um instrumento para difusão cultural de acervos arquivísticos. In: ANDRADE, A. C. N. (Org.). Arquivos, entre tradição e modernidade, volume 2: trabalhos apresentados nas sessões de comunicações livres e os eventos paralelos do XI Congresso de Arquivologia do Mercosul. São Paulo: ARQ-SP, 2017. p. 138-150.

MOURA, R.L.; DINIZ, B.D. Analisando projetos através das práticas: um ensaio teórico. Revista de Gestão e Projetos - GeP, v. 7, n. 2. p. 34-41, 2016.

PENNYCOOK, A. Posthumanist Applied Linguistics. Applied Linguistics, v. 39, n. 4, p. 445-461, 2018.

PICKERING, A. Living in the material world. In: VAUJANY, FX; MITEV, N. (Eds.). Materiality and Space: organizations, artefacts and practices., London: Palgrave Macmillan, 2013. p. 25-40.

PICKERING, A. Practice and post-humanism: social theory and a history of agency. In: SCHATZKI, T.R.; KNORR-CETINA, K.; VON SAVIGNY, E. (Ed.). The practice turn in contemporary. London: Routledge, 2001. p. 172-183.

POSTMA, D. Education as sociomaterial critique. Pedagogy, Culture Society, v. 20, n. 1, p. 137-156, 2012.

RODRIGUES, A.C. Diplomática contemporânea como fundamento metodológico da identificação da tipologia documental em arquivos. 2008. Tese (Doutorado em História Social) - Faculdade de Filosofia, Letras e Ciências Humanas, Programa de Pós-Graduação em História Social, Universidade de São Paulo, 2008.

ROSSATO, F.H.C.; FLORES, D. O documento arquivístico: reflexões acerca do patrimônio cultural. ScientiaTec: Revista de Educação, Ciência e Tecnologia do IFRS-Campus Porto Alegre, Porto Alegre, v. 2 n. 3, p. 35-47, jul/dez. 2015.

SCHATZKI, T.R. Introduction: practice theory. In: SCHATZKI, T.R.; KNORR-CETINA, K; VON SAVIGNY, E. (Ed.). The practice turn in contemporary. London: Routledge, 2001a. 
SCHATZKI, T.R. Practice mind-ed orders. In: SCHATZKI, T.R.; KNORR-CETINA, K.; VON SAVIGNY,

E. (Ed.). The practice turn in contemporary. London: Routledge, 2001b. p. 50-63.

SCHLOSSER, M. Agency. 2015. Available in: https://plato.stanford.edu/archives/fall2015/entries/ agency/. Accessed 10.02.2018.

SØRENSEN, E. The Materiality of Learning: Technology and Knowledge in Educational Practice. Cambridge University Press, 2009.

ST. PIERRE, E.A. Uma história breve e pessoal da pesquisa pós-qualitativa: em direção à "pósinvestigação". Práxis Educativa, Ponta Grossa, v. 13, n. 3, p. 1044-1064, set./dez. 2018b. Available in: https://www.revistas2.uepg.br/index.php/praxiseducativa. Accessed 5.01.2019.

ST. PIERRE, E.A. Writing Post Qualitative Inquiry. Qualitative Inquiry, v. 24, n. 9, p. 603-608, 2018a.

TAYLOR, C.A. Is a posthumanist Bildung possible? Reclaiming the promise of Bildung for contemporary higher education, Higher Education, v. 74, n. 3, p. 419-435, 2017.

ULMER, J.B. Posthumanism as research methodology: inquiry in the Anthropocene. International Journal of Qualitative Studies in Education, 2017. Available in: http://www.ufrpe.br/sites/ www.ufrpe.br/files/ulmer_2017._posthumanism_as_research.pdf. Accessed 4.10.2019.

WALTZ, S.B. Nonhumans Unbound: Actor-Network Theory and the Reconsideration of "Things" in Educational Foundations. Educational Foundations, v. 20, n. 3-4, p. 51-68, 2006. 